\title{
VARIASI PERTUMBUHAN BIBIT MERANTI TEMBAGA (Shorea leprosula) ASAL CABUTAN UNTUK PEMBANGUNAN TANAMAN PANGKAS
}

\author{
Growth Variation of Shorea leprosula Seedlings from Wildling \\ for Material of Cutting Plants Development \\ Mashudi ${ }^{1}$ dan/and Dedy Dwi Nur Cahyono ${ }^{2)}$ \\ ${ }^{1)}$ Balai Besar Penelitian Bioteknologi dan Pemuliaan Tanaman Hutan \\ Jl. Palagan Tentara Pelajar Km.15 Purwobinangun, Pakem, Sleman, Yogyakarta. 55582 \\ Telp. 0274-895954 ; Fax. 0274-896080 \\ E-mail: masshudy@yahoo.com \\ ${ }^{2)}$ Balai Besar Penelitian Dipterokarpa \\ Jl. A. Wahab Syahrani Sempaja No. 6 \\ Kotak Pos 1206 Samarinda \\ Telp. 0541-206364 ; Fax. 0541-742298
}

Naskah masuk : 7 Februari 2014; Naskah diterima : 31 Maret 2015

\begin{abstract}
The study aims identify growth variation and sprouting ability of wild seedling from two populations with different condition for material of hedge orchard development. This experiment used completely randomized design with nested pattern. The research used 2 factors, i.e. population sources (Muara Wahau and Berau, East Kalimantan) and parent trees (20 parent trees from Muara Wahau and 14 parent trees from Berau). Parent trees factor was nested in the population sources. The result showed that population sources and parent trees significantly affected the parameters measured, i.e. height, stem diameter, number of branch, number of sprouts and length of sprouts. Muara Wahau population produced better average of height, stem diameter, number of branch, number of sprouts and length of sprouts. The best seedling for growth of height, stem diameter, number of branch, number of sprouts and lenght of sprouts were dominated by parent trees from Muara Wahau.
\end{abstract}

Keywords: Population sources, wildling, parent trees, Shorea leprosula, growth variation

\begin{abstract}
ABSTRAK
Tulisan ini bertujuan untuk mengetahui variasi pertumbuhan dan daya pertunasan bibit meranti tembaga asal cabutan dari dua populasi dengan kondisi berbeda sebagai materi untuk pembuatan tanaman pangkas. Rancangan percobaan yang digunakan adalah Rancangan Acak Lengkap (RAL) pola tersarang yang terdiri dari 2 faktor, yaitu asal populasi (Muara Wahau dan Berau, Kalimantan Timur) dan pohon induk (20 pohon induk dari Muara Wahau dan 14 pohon induk dari Berau). Dalam penelitian ini faktor pohon induk bersarang (nested) dalam faktor asal populasi. Hasil penelitian menunjukkan bahwa perlakuan asal populasi dan pohon induk berpengaruh sangat signifikan terhadap parameter yang diamati, yaitu tinggi, diameter batang, jumlah percabangan, jumlah tunas dan panjang tunas. Populasi Muara Wahau menghasilkan rata-rata pertumbuhan tinggi, diameter batang, jumlah percabangan, jumlah tunas dan panjang tunas lebih baik dari populasi Berau. Bibit-bibit terbaik dalam pertumbuhan tinggi, diameter batang, jumlah percabangan, jumlah tunas dan panjang tunas didominasi oleh pohon induk dari populasi Muara Wahau.
\end{abstract}

Kata kunci: Asal populasi, cabutan, pohon induk, shorea leprosula, variasi pertumbuhan

\section{PENDAHULUAN}

Pembangunan hutan tanaman dengan produktivitas tinggi untuk memasok kebutuhan kayu sebagai bahan baku industri perlu segera diwujudkan karena produksi kayu dari hutan alam di luar Jawa cenderung menurun dari tahun ke tahun. Salah satu jenis lokal (indegenous species) yang mempunyai prospek yang baik untuk pengembangan hutan tanaman di luar Jawa adalah meranti tembaga (Shorea leprosula Miq.). Di Indonesia meranti tembaga menyebar secara alami di Sumatera, Kalimantan dan Maluku (Danu et al., 2010). IFSP (2002) menyampaikan bahwa jenis ini merupakan jenis meranti yang mempunyai pertumbuhan paling cepat dan dapat ditebang pada umur 20 tahun. Naiem et al. (2004) menyampaikan bahwa riap diameter batang 
tanaman uji keturunan meranti tembaga umur 4 tahun di PT. Balikpapan Forest Industries, Kalimantan Timur, berkisar antara 1,66-2,38 $\mathrm{cm} /$ tahun dan riap tinggi berkisar antara 1,5-2,6 $\mathrm{m} /$ tahun tahun. Eksploitasi terhadap jenis ini berlangsung intensif karena kayunya sangat diminati oleh para pengusaha kayu untuk bahan baku mebel, panel, lantai, langit-langit dan kayu lapis. Tingginya laju eksploitasi jenis ini menyebabkan penurunan populasi yang cepat sehingga menurut daftar IUCN tergolong langka (IFSP, 2002).

Pada saat ini pengembangan hutan tanaman dengan produktivitas tinggi di luar Jawa dijawantahkan melalui penerapan teknik silvikultur intensif (SILIN). Dalam teknik SILIN, meranti tembaga dijadikan sebagai spesies standar karena sebarannya luas sehingga mudah didapat di seluruh pulau Sumatera dan Kalimantan. Salah satu faktor yang harus diperhatikan dalam pengembangan hutan tanaman meranti tembaga adalah pengadaan bibit tanaman berkualitas dalam jumlah cukup secara berkesinambungan, baik dari materi generatif atau vegetatif. Pada saat ini pengadaan bibit dari materi generatif masih menghadapi kendala karena sifat bijinya rekalsitran dan musim berbunganya tidak berlangsung setiap tahun. Terkait dengan permasalahan tersebut, maka perbanyakan vegetatif dapat dijadikan solusi alternatif untuk penyediaan bibit meranti tembaga. Diketahui bahwa perbanyakan vegetatif dari materi tua sulit dilakukan pada jenis ini, sehingga untuk mendapatkan persen jadi yang tinggi harus digunakan materi yang muda. Berdasarkan hasil penelitian Danu et al. (2010), persen berakar stek pucuk meranti tembaga dari materi tanaman umur muda ( \pm 2 tahun) dengan sistem KOFFCO relatif tinggi yaitu sebesar $88,33 \%$.

Tahap awal yang dapat dilakukan untuk melakukan perbanyakan vegetatif meranti tembaga adalah dengan membangun tanaman pangkas sebagai penyedia materi stek. Untuk menghasilkan bibit yang berkualitas, tanaman pangkas dibangun dari pohon-pohon yang berfenotipe bagus karena pada perbanyakan secara vegetatif (klonal) seluruh potensi genetik pohon induk baik varians genetik aditif dan nonaditif akan diwariskan kepada keturunannya. Untuk mendapatkan bibit meranti tembaga berkualitas dari materi vegetatif, maka dilakukan pengambilan materi genetik (anakan) dari hutan alam. Bibit-bibit dari anakan pohon induk yang secara fenotipik bagus dikoleksi, selanjutnya dibesarkan di persemaian kemudian diseleksi berdasarkan pertumbuhannya. Bibit-bibit dengan pertumbuhan bagus selanjutnya diuji daya pertunasan dan daya perakarannya. Bibit-bibit dengan daya pertunasan dan daya perakaran tinggi selanjutnya akan dimanfaatkan sebagai tanaman pangkas untuk penyedia materi stek.

Tujuan penelitian adalah untuk mengetahui variasi pertumbuhan dan daya pertunasan bibit meranti tembaga asal cabutan dari dua populasi dengan kondisi berbeda sebagai materi untuk pembuatan tanaman pangkas. Hasil penelitian ini dalam jangka pendek dapat dimanfaatkan untuk pengembangan tanaman pangkas meranti tembaga yang berkualitas.

\section{METODOLOGI}

\section{A. Lokasi dan Waktu}

Penelitian dilaksanakan di persemaian Balai Besar Penelitian Bioteknologi dan Pemuliaan Tanaman Hutan, Yogyakarta. Secara geografis lokasi penelitian berada pada $7^{\circ} 40^{\prime} 35^{\prime \prime} \mathrm{LS}$ dan $110^{\circ} 23^{\prime} 23^{\prime \prime B T}, 287 \mathrm{~m}$ di atas permukaan laut, curah hujan rata-rata $1.878 \mathrm{~mm} /$ tahun, suhu ratarata $27^{\circ} \mathrm{C}$ dan kelembaban relatif $73 \%$. Kegiatan penelitian dilaksanakan mulai Maret 2010 sampai dengan Agustus 2011.

\section{B. Bahan dan Alat}

Bahan yang dipergunakan adalah bibit meranti tembaga asal cabutan umur 18 bulan di persemaian yang dikoleksi dari 2 populasi, yaitu Muara Wahau dan Berau, Kalimantan Timur. Bahan-bahan yang lain adalah polybag ukuran $12 \times 15 \mathrm{~cm}$, dan ukuran $25 \times 25 \mathrm{~cm}$, top soil, kompos, pupuk NPK 16-16-16, sarlon, fungisida dan insektisida, sedangkan alat yang dipergunakan antara lain adalah cangkul, sekop, sprayer, gunting stek, kaliper, selang, penggaris, kertas label, kamera dan alat tulis menulis.

\section{Pelaksanaan Penelitian}

Tahapan penelitian yang dilakukan meliputi:

\section{Koleksi materi genetik}

Materi genetik yang dikoleksi berupa anakan meranti tembaga yang berasal dari Muara Wahau dan Berau, Kalimantan Timur. Populasi Muara Wahau berada pada areal Konsesi Izin Usaha Pemanfaatan Hasil Hutan Kayu Hutan Alam (IUPHHK-HA) yang masih aktif beroperasi, sedang populasi Berau berada pada areal bekas IUPHHK-HA yang 
sudah tidak beroperasi. Untuk memperoleh bibit yang berkualitas terlebih dahulu dilakukan pemilihan pohon induk. Pohon induk dengan penampilan bagus (tinggi, diameter besar, lurus dan sehat) dipilih sebagai pohon indukan. Pengambilan bibit dilakukan dengan cara memilih bibit-bibit dengan kisaran tinggi antara $25-35 \mathrm{~cm}$ yang kondisinya bagus dan berada di bawah tajuk pohon induk terpilih, sehingga bibit yang dikoleksi diharapkan merupakan anakan dari pohon induk yang terpilih. Pengambilan bibit sengaja dilakukan dari dua populasi yang jaraknya tidak terlalu jauh, sehingga diharapkan bibit yang diambil berasal dari biji pada musim buah yang bersamaan sehingga umurnya relatif sama. Berdasarkan informasi dari lapangan bibit yang dikoleksi berasal dari musim buah 2 tahun sebelum pengambilan materi.

\section{Pembibitan}

Kegiatan pembibitan diawali dengan penyiapan media tanam berupa campuran top soil + kompos (4:1). Kegiatan selanjutnya adalah penanaman bibit meranti tembaga ke dalam polybag ukuran $12 \times 15 \mathrm{~cm}$ dengan media bibit yang sudah dipersiapkan. Bibitbibit yang telah ditanam dalam polibag selanjutnya ditempatkan di dalam bedeng persemaian. Untuk menjaga kelembaban, bedeng persemaian dipasang sungkup plastik dan untuk mengurangi intensitas cahaya di atas bedeng persemaian dipasang sarlon dengan kerapatan $65 \%$. Pada tahap ini jumlah bibit yang ditanam sebanyak 25 bibit/pohon induk. Setelah 3 bulan dari penanaman sungkup plastik dibuka.

\section{Pemeliharaan bibit}

Kegiatan pemeliharaan yang dilakukan adalah penyiraman, penyiangan dan pengendalian hama/penyakit. Kegitan penyiraman dilakukan $1 \mathrm{kali} /$ hari, yaitu pada pagi hari. Kegiatan penyiangan dilakukan secara rutin (sebulan sekali). Pengendalian hama dan penyakit dilakukan secara rutin (2 minggu sekali) dengan menggunakan insektisida dan fungisida.

\section{Seleksi bibit}

Seleksi bibit dilakukan untuk memilih pertumbuhan 6 bibit terbaik per pohon induk. Seleksi dilakukan pada saat bibit berumur 8 bulan setelah penanaman. Bibit-bibit yang terseleksi selanjutnya dipindah dalam polybag ukuran 25 × $25 \mathrm{~cm}$ dan dipupuk NPK
16-16-16 dengan dosis 10 gram untuk setiap tanaman agar pertumbuhannya tetap optimal.

\section{Pengambilan data pertumbuhan}

Pengambilan data dilakukan dua kali yaitu pada awal penelitian dan saat bibit berumur 18 bulan. Dari dua kali pengukuran tersebut akan diketahui respon pertumbuhannya. Karakter yang didata meliputi: tinggi bibit, diameter batang dan jumlah percabangan.

\section{Pemangkasan}

Setelah dilakukan pengambilan data pertumbuhan, selanjutnya dilakukan seleksi untuk memilih 2 bibit terbaik dari masingmasing pohon induk. Bibit-bibit terseleksi selanjutnya dipangkas pada ketinggian $60 \mathrm{~cm}$ dan dihilangkan semua daunnya.

\section{Pengambilan data daya pertunasan}

Empat bulan setelah pemangkasan kemudian dilakukan pengambilan data untuk mengetahui daya pertunasan (sprouting ability) masing-masing bibit. Karakter yang didata adalah jumlah tunas dan panjang tunas.

\section{Rancangan Penelitian}

Untuk mengetahui respon pertumbuhan bibit meranti tembaga, penelitian dilaksanakan dengan menggunakan Rancangan Acak Lengkap (RAL) pola tersarang yang terdiri dari 2 faktor, yaitu asal populasi (A) dan pohon induk (B). Dalam penelitian ini faktor B tersarang (nested) pada faktor A. Faktor A terdiri dari 2 asal populasi, yaitu: A1 = asal populasi Muara Wahau, Kalimantan Timur dan A2 = asal populasi Berau, Kalimantan Timur. Faktor B terdiri dari 34 pohon induk, yaitu 20 pohon induk berasal dari Muara Wahau dan 14 pohon induk berasal dari Berau. Untuk masing-masing pohon induk digunakan 6 bibit, sehingga jumlah bibit yang dipergunakan dalam penelitian ini sebanyak 34 × $6=204$ individu. Untuk megetahui daya pertunasan (sprouting ability) masing-masing pohon induk dipilih dua bibit yang terbaik, sehingga jumlah bibit yang diamati sebanyak $34 \times 2=68$ individu.

\section{E.Analisis Data}

Data hasil pengamatan dan pengukuran dianalisis menurut prosedur Rancangan Acak Lengkap pola tersarang. Untuk mengetahui perlakuan yang berpengaruh nyata dilakukan analisis sidik ragam (analisis varians) menggunakan model $\mathrm{Y}_{i j}=\mu+\mathrm{T}_{i}+\beta_{j}\left(\mathrm{~T}_{i}\right)+\varepsilon_{i j}$, dengan: $\mathrm{Y}_{i j}=$ rata-rata pengamatan pada asal populasi ke-i,pohon induk ke-j; $\mu=$ rata-rata 
umum; $\mathrm{T}_{\mathrm{i}}=$ pengaruh asal populasi ke-i; $\beta_{j}\left(\mathrm{~T}_{i}\right)=$ pengaruh pohon induk ke-j yang tersarang dalam populasi ke-i dan $\varepsilon_{i j}=$ galat.

Apabila hasil analisis varians menunjukkan perbedaan yang signifikan, maka dilanjutkan dengan Uji Duncan Multiple Range Test (DMRT) untuk mengetahui perbedaan pengaruh masingmasing perlakuan.

\section{HASIL DAN PEMBAHASAN}

\section{A. Hasil}

Berdasarkan hasil pengamatan dan pengukuran, persen hidup bibit saat seleksi (umur 8 bulan) sampai dengan saat pengukuran (umur 18 bulan) relatif tinggi yaitu sebesar 95,59\%. Hasil perhitungan menunjukkan bahwa pertumbahan tinggi, diameter batang dan jumlah percabangan bibit cukup bervariasi. Rata-rata pertumbuhan tinggi bibit berkisar antara 35,8-136,5 cm, pertumbuhan diameter batang berkisar antara 3,53-10,22 $\mathrm{mm}$ dan pertumbuhan jumlah percabangan berkisar antara $1,8-8,83$ cabang per tanaman. Untuk aspek daya pertunasan, parameter jumlah tunas dan panjang tunas bibit meranti tembaga juga cukup bervariasi. Hasil perhitungan menunjukkan bahwa rata-rata jumlah tunas berkisar antara 2,5-9,5 buah per tanaman dan rata-rata panjang tunas berkisar antara 9,25 $-31,15 \mathrm{~cm}$. Untuk mengetahui pengaruh per-

Tabel(Table) 1. Hasil analisis varians pertumbuhan dan daya pertunasan bibit meranti tembaga asal cabutan (Variance analysis of growth and sprouting ability of Shorea leprosula seedling from wildling)

\begin{tabular}{|c|c|c|c|c|}
\hline \multicolumn{5}{|c|}{ Pertumbuhan (growth) } \\
\hline $\begin{array}{c}\text { Sumber Variasi } \\
\text { (Source of variation) }\end{array}$ & $\begin{array}{l}\text { Derajat } \\
\text { Bebas } \\
\text { (Degree of } \\
\text { freedom) }\end{array}$ & $\begin{array}{l}\text { Tinggi bibit } \\
\text { (Height of } \\
\text { seedling) }\end{array}$ & $\begin{array}{r}\text { Diameter batang } \\
\text { (Stem diameter) }\end{array}$ & $\begin{array}{c}\text { Jumlah bercabangan } \\
\text { (Number of } \\
\text { branches) }\end{array}$ \\
\hline $\begin{array}{l}\text { Populasi (A) } \\
\text { (population) }\end{array}$ & 1 & $87054,43345 * *)$ & $211,61939 * *)$ & $515,80825 * *)$ \\
\hline $\begin{array}{l}\text { Pohon Induk }\{\mathrm{B}(\mathrm{A})\} \\
\text { (parent trees) }\end{array}$ & 32 & $1904,72101 * *)$ & $12,34296 * *)$ & $8,66018 * *)$ \\
\hline Sisa (error) & 161 & 354,1545 & 3,92154 & 3,02020 \\
\hline Total (total) & 194 & & & \\
\hline \multicolumn{5}{|c|}{ Daya pertunasan (sprouting ability) } \\
\hline $\begin{array}{c}\text { Sumber Variasi } \\
\text { (Source of variation) }\end{array}$ & $\begin{array}{c}\text { Derajat bebas } \\
\text { (Degree of } \\
\text { Freedom) }\end{array}$ & $\begin{array}{l}\text { Jumlah to } \\
\text { (Number of }\end{array}$ & uts) & $\begin{array}{l}\text { Panjang tunas } \\
\text { (Lenght of sprouts) }\end{array}$ \\
\hline $\begin{array}{l}\text { Populasi (A) } \\
\text { (Population) }\end{array}$ & 1 & 40,76772 & & $196,82176 * *)$ \\
\hline $\begin{array}{l}\text { Pohon Induk }\{\mathrm{B}(\mathrm{A})\} \\
(\text { Parent trees })\end{array}$ & 32 & 4,44564 & & $51,59103 * *)$ \\
\hline Sisa (Error) & 34 & 0,90996 & & 6,92371 \\
\hline Total (Total) & 67 & & & \\
\hline
\end{tabular}

Keterangan $\left(\right.$ Remarks) $\left.:{ }^{* *}\right)=$ berbeda nyata pada taraf 0,01 (Significantly different on $F=1 \%$ ). 
Tabel (Table) 2. Rata-rata pertumbuhan (tinggi, diameter batang dan jumlah percabangan) dan daya pertunasan (jumlah tunas dan panjang tunas) bibit meranti tembaga umur 18 bulan dari dua populasi (Growth average (height, stem diameter and number of branches) and sprouting ability (number of sprouts and lenght of sprouts) at 18 month of age Shorea leprosula seedling from 2 populations)

\begin{tabular}{|c|c|c|}
\hline \multirow{2}{*}{$\begin{array}{c}\text { Karakter } \\
\text { (Character) }\end{array}$} & \multicolumn{2}{|c|}{ Asal populasi (Population sources) } \\
\hline & Muara Wahau & Berau \\
\hline $\begin{array}{l}\text { Tinggi bibit }(\mathrm{cm}) * *) \\
(\text { Height })\end{array}$ & $108,21 \mathrm{a}$ & $65,08 \mathrm{~b}$ \\
\hline $\begin{array}{l}\text { Diameter batang }(\mathrm{mm}) * *) \\
\text { (Stem diameter) }\end{array}$ & 8,52 a & $6,42 \mathrm{~b}$ \\
\hline $\begin{array}{l}\text { Jumlah percabangan } * * \text { ) } \\
\text { (Number of branches) }\end{array}$ & $7,73 \mathrm{a}$ & $4,42 \mathrm{~b}$ \\
\hline $\begin{array}{l}\text { Jumlah tunas } * * \text { ) } \\
\text { (Number of sprouts) }\end{array}$ & $6,30 \mathrm{a}$ & $4,64 \mathrm{~b}$ \\
\hline $\begin{array}{l}\text { Panjang tunas }(\mathrm{cm}) * *) \\
\text { (Lenght of sprouts) }\end{array}$ & 20,13 a & $16,49 \mathrm{~b}$ \\
\hline
\end{tabular}

Keterangan : **) $=$ huruf yang sama pada baris yang sama menunjukkan berbeda tidak nyata pada taraf 0,01 , (Remarks): (Number followed by the same letter in the same row are significantly different on $F=1 \%$.)

lakuan terhadap parameter yang diamati dilakukan ana-lisis varians sebagaimana disajikan pada Tabel 1.

Tabel 1 menunjukkan bahwa perlakuan asal populasi (A) dan pohon induk (B) berpengaruh sangat nyata terhadap pertumbuhan (tinggi, diameter batang dan jumlah percabangan) dan daya pertunasan (jumlah tunas dan panjang tunas) bibit meranti tembaga.

Hasil Uji Jarak Berganda Duncan (DMRT) efek asal populasi terhadap parameter pertumbuhan (tinggi, diameter batang dan jumlah percabangan) dan daya pertunasan (jumlah tunas dan panjang tunas) bibit meranti tembaga disajikan pada Tabel 2.

Tabel 2 menunjukkan bahwa pertumbuhan tinggi bibit, diameter batang, jumlah percabangan, jumlah tunas dan panjang tunas populasi Muara Wahau lebih baik dari populasi Berau.

Hasil Uji Jarak Berganda Duncan (DMRT) efek pohon induk terhadap parameter pertumbuhan (tinggi, diameter batang dan jumlah percabangan) dan daya pertunasan (jumlah tunas dan panjang tunas) bibit meranti tembaga disajikan pada Tabel 3 .

Tabel 3 menunjukkan bahwa 11 pohon induk dari Muara Wahau memiliki rata-rata tinggi bibit yang sama dan menempati posisi yang terbaik. Pada parameter diameter batang, 21 pohon induk memiliki rata-rata diameter batang yang sama dan menempati posisi terbaik (17 pohon induk berasal dari Muara Wahau dan 4 pohon induk berasal dari Berau). Dua puluh pohon induk memiliki rata-rata jumlah percabangan yang sama dan menempati posisi terbaik (18 pohon induk berasal dari Muara Wahau dan 2 pohon induk berasal dari Berau). Untuk jumlah tunas, pohon induk yang memiliki rata-rata jumlah tunas sama dan menempati posisi terbaik sebanyak 7 pohon induk (5 pohon induk dari Muara Wahau dan 2 pohon induk berasal dari Berau). Kemudian untuk panjang tunas, pohon induk yang memiliki rata-rata panjang tunas sama dan menempati posisi terbaik sebanyak 3 pohon induk ( 2 pohon induk berasal dari Muara Wahau dan 1 pohon induk berasal dari Berau). 
Tabel (Table) 3. Hasil uji DMRT pertumbuhan tinggi bibit, diameter batang, jumlah percabangan, jumlah tunas dan panjang tunas bibit meranti tembaga asal cabutan (Result of DMRT test on growth of height, stem diameter, number of branches, number of sprouts and lenght of sprouts S. leprosula seedling from wildling)

\begin{tabular}{|c|c|c|c|c|c|c|c|c|c|}
\hline \multicolumn{2}{|c|}{$\begin{array}{c}\text { Tinggi bibit } \\
\text { (Seedling height) }\end{array}$} & \multicolumn{2}{|c|}{$\begin{array}{l}\text { Diameter batang } \\
\text { (Stem diameter) }\end{array}$} & \multicolumn{2}{|c|}{$\begin{array}{l}\text { Jumlah percabangan } \\
\text { (Number of branches) }\end{array}$} & \multicolumn{2}{|c|}{$\begin{array}{c}\text { Jumlah tunas } \\
\text { (Number of sprouts) }\end{array}$} & \multicolumn{2}{|c|}{$\begin{array}{c}\text { Panjang tunas } \\
\text { (Lenght of sprouts) }\end{array}$} \\
\hline $\begin{array}{l}\text { Pohon } \\
\text { induk } \\
\text { (Paren } \\
\text { t trees) }\end{array}$ & $\begin{array}{l}\text { Rata-rata } \\
\text { tinggi } \\
\text { (Average of } \\
\text { height) } \\
(\mathrm{cm})\end{array}$ & $\begin{array}{l}\text { Pohon } \\
\text { induk } \\
\text { (Paren } \\
\text { t trees) }\end{array}$ & $\begin{array}{l}\text { Rata-rata } \\
\text { percabangan } \\
\text { (Average of } \\
\text { stem } \\
\text { diameter) } \\
(\mathrm{mm}) \\
\end{array}$ & $\begin{array}{l}\text { Pohon } \\
\text { induk } \\
\text { (Paren } \\
\text { t trees) }\end{array}$ & $\begin{array}{l}\text { Rata-rata } \\
\text { percabangan } \\
\text { (Average of } \\
\text { branches) }\end{array}$ & $\begin{array}{l}\text { Pohon } \\
\text { induk } \\
\text { (Paren } \\
\text { t trees) }\end{array}$ & $\begin{array}{l}\text { Rata-rata } \\
\text { jumlah tunas } \\
\text { (Average of } \\
\text { number of } \\
\text { sprouts) }\end{array}$ & $\begin{array}{l}\text { Pohon } \\
\text { induk } \\
\text { (Paren } \\
\text { t trees) }\end{array}$ & $\begin{array}{l}\text { Rata-rata } \\
\text { panjang tunas } \\
\text { (Average of } \\
\text { lenght of } \\
\text { sprouts) } \\
(\mathrm{cm}) \\
\end{array}$ \\
\hline 19 & $136,5 \mathrm{a}$ & 19 & $10,22 \mathrm{a}$ & 13 & $8,8 \mathrm{a}$ & 19 & $9,5 \mathrm{a}$ & 1 & $31,2 \mathrm{a}$ \\
\hline 20 & $127,8 \mathrm{ab}$ & 1 & $10,20 \mathrm{a}$ & 3 & $8,7 \mathrm{ab}$ & 32 & $8,0 \mathrm{ab}$ & 19 & $30,7 \mathrm{a}$ \\
\hline 7 & $124,3 \mathrm{abc}$ & 7 & $9,77 \mathrm{ab}$ & 9 & $8,7 \mathrm{ab}$ & 27 & $8,0 \mathrm{ab}$ & 29 & $26,4 \mathrm{ab}$ \\
\hline 17 & $124,0 \mathrm{abc}$ & 6 & $9,61 \mathrm{ab}$ & 11 & $8,5 \mathrm{ab}$ & 2 & $7,5 a b c$ & 7 & $24,8 \mathrm{bc}$ \\
\hline 11 & $121,7 \mathrm{abc}$ & 2 & $9,38 \mathrm{ab}$ & 1 & $8,5 \mathrm{ab}$ & 17 & $7,5 \mathrm{abc}$ & 13 & $24,8 \mathrm{bc}$ \\
\hline 15 & 118,3 abcd & 17 & $9,26 \mathrm{abc}$ & 19 & $8,5 \mathrm{ab}$ & 4 & $7,5 \mathrm{abc}$ & 6 & $23,0 \mathrm{bcd}$ \\
\hline 9 & 117,8 abcd & 3 & $9,26 \mathrm{abc}$ & 17 & $8,5 \mathrm{ab}$ & 9 & $7,5 a b c$ & 27 & $23,0 \mathrm{bcd}$ \\
\hline 1 & $\begin{array}{l}115,8 \\
\text { abcde }\end{array}$ & 11 & $9,25 \mathrm{abc}$ & 6 & $8,4 \mathrm{ab}$ & 6 & $7,0 \mathrm{bcd}$ & 24 & 22,4 bcde \\
\hline 18 & $\begin{array}{r}114,7 \\
\text { abcde }\end{array}$ & 4 & 9,06 abc & 15 & $8,3 \mathrm{ab}$ & 1 & $7,0 \mathrm{bcd}$ & 2 & 22,4 bcde \\
\hline 16 & $\begin{array}{l}113,2 \\
\text { abcde }\end{array}$ & 27 & $8,93 \mathrm{abc}$ & 20 & $8,0 \mathrm{abc}$ & 20 & 7,0 bcd & 12 & 22,2 bcdef \\
\hline 3 & $\begin{array}{l}112,8 \\
\text { abcde }\end{array}$ & 9 & $8,91 \mathrm{abc}$ & 18 & $7,7 \mathrm{abc}$ & 3 & $7,0 \mathrm{bcd}$ & 15 & 21,2 bcdefg \\
\hline 6 & 109,4 bcde & 32 & 8,71 abcd & 16 & $7,7 \mathrm{abc}$ & 7 & 6,5 bcde & 17 & 20,8 bcdefg \\
\hline 4 & 106,5 bcdef & 13 & 8,54 abcde & 7 & $7,7 a b c$ & 11 & 6,5 bcde & 10 & 20,5 bcdefgh \\
\hline 2 & 105,5 bcdef & 15 & $\begin{array}{c}8,44 \\
\text { abcdef }\end{array}$ & 2 & 7,3 abcd & 14 & 6,0 bcdef & 20 & 19,9 cdefghi \\
\hline 32 & 100,8 cdefg & 20 & $\begin{array}{c}8,37 \\
\text { abcdef }\end{array}$ & 10 & 7,2 abcd & 15 & 6,0 bcdef & 23 & 19,9 cdefghi \\
\hline 13 & 94,8 defgh & 18 & $\begin{array}{c}8,24 \\
\text { abcdef }\end{array}$ & 4 & 7,2 abcd & 10 & 5,5 cdefg & 5 & 19,1 cdefghi \\
\hline 27 & 94,8 defgh & 24 & $\begin{array}{c}8,06 \\
\text { abcdef }\end{array}$ & 27 & 7,2 abcd & 16 & 5,5 cdefg & 11 & 18,3 defghij \\
\hline 10 & 91,8 defghi & 16 & $\begin{array}{c}7,97 \\
\text { abcdef }\end{array}$ & 12 & 6,8 abcde & 18 & 5,5 cdefg & 18 & 17,8 defghij \\
\hline 12 & 90,3 efghi & 12 & $\begin{array}{c}7,78 \\
\text { abcdef }\end{array}$ & 14 & 6,3 abcde & 34 & 5,5 cdefg & 3 & 17,0 defghijk \\
\hline 14 & 83,2 fghij & 10 & $\begin{array}{c}7,74 \\
\text { abcdef }\end{array}$ & 32 & 6,3 abcde & 13 & 5,0 defgh & 21 & 16,9 defghijk \\
\hline 24 & 82,3 fghij & 29 & $\begin{array}{c}7,63 \\
\text { abcdef }\end{array}$ & 8 & 6,2 bcde & 33 & 5,0 defgh & 4 & 16,4 efghijk \\
\hline 5 & 77,8 ghijk & 14 & 7,20 bcdef & 5 & 5,7 cdef & 12 & $5 ., 0$ defgh & 28 & 16,1 efghijk \\
\hline 30 & 77,0 ghijk & 33 & 6,90 bcdef & 24 & $5,7 \mathrm{cdef}$ & 24 & 5,0 defgh & 26 & 16,0 efghijk \\
\hline 8 & 75,3 ghijk & 34 & 6,48 cdefg & 26 & $5,2 \mathrm{def}$ & 5 & 4,5 efghi & 16 & 16,0 fghijk \\
\hline 33 & 70,0 hijk & 21 & 6,46 cdefg & 30 & $5,0 \mathrm{def}$ & 21 & 4,5 efghi & 32 & 15,4 ghijkl \\
\hline 29 & $67,7 \mathrm{ijkl}$ & 26 & 6,38 cdefg & 21 & 4,7 efg & 26 & 4,5 efghi & 33 & 14,2 hijkl \\
\hline 21 & $62,3 \mathrm{jkl}$ & 22 & 5,93 defgh & 33 & 4,6 efg & 29 & 4,0 efghi & 34 & $13,7 \mathrm{ijkl}$ \\
\hline 34 & $59,8 \mathrm{jklm}$ & 25 & 5,87 defgh & 29 & $4,5 \mathrm{efg}$ & 30 & 4,0 fghi & 14 & 13,6 ijkl \\
\hline 26 & $55,2 \mathrm{klm}$ & 5 & $5,70 \mathrm{efgh}$ & 34 & 4,4 efgh & 25 & 4,0 fghi & 30 & $13,5 \mathrm{ijkl}$ \\
\hline 22 & $54,8 \mathrm{klm}$ & 30 & $5,61 \mathrm{fgh}$ & 22 & 3,6 fghi & 22 & 3,5 ghi & 9 & $12,7 \mathrm{jkl}$ \\
\hline 25 & $52,2 \mathrm{klm}$ & 8 & $5,60 \mathrm{fgh}$ & 31 & 3,4 fghi & 31 & 3,5 ghi & 25 & $12,3 \mathrm{jkl}$ \\
\hline 31 & $43,2 \mathrm{~lm}$ & 23 & $4,02 \mathrm{gh}$ & 23 & 2,4 ghi & 23 & 3,0 hi & 22 & $12,1 \mathrm{jkl}$ \\
\hline 28 & $43,2 \mathrm{~lm}$ & 31 & $3,93 \mathrm{gh}$ & 25 & $2,2 \mathrm{hi}$ & 28 & $2,5 \mathrm{i}$ & 8 & $10,6 \mathrm{kl}$ \\
\hline 23 & $35,8 \mathrm{~m}$ & 28 & $3,53 \mathrm{~h}$ & 28 & $1,8 \mathrm{i}$ & 8 & $2,5 \mathrm{i}$ & 31 & 9,251 \\
\hline
\end{tabular}

Keterangan(Remarks) : Pohon Induk 1 - 20: populasi Muara Wahau, Kalimantan Timur. (Parent tress 1 - 20: Muara Wahau population, East Kalimantan). Pohon Induk 21 - 34: populasi Berau, Kalimantan Timur (Parent tress 21 - 34: Berau population, East Kalimantan). 


\section{B. Pembahasan}

\section{Variasi antar populasi}

Hasil analisis varians (Tabel 1) menunjukkan bahwa perlakuan asal populasi berpengaruh sangat nyata terhadap pertumbuhan tinggi, diameter batang, jumlah percabangan, jumlah tunas dan panjang tunas bibit meranti tembaga. Hal ini sejalan dengan hasil penelitian Mashudi et al. (2012) serta Mashudi dan Susanto (2013) terhadap pertumbuhan bibit meranti tembaga hasil persemaian dari biji, dimana pertumbuhan bibit dan daya pertunasan antar populasi berbeda nyata. Hal ini dapat dipahami karena keragaman genetik dalam populasi jenis meranti tembaga relatif besar (70,2\%) (Cao et al., 2006), sehingga masing-masing populasi dengan individu-individu yang bervariasi akan melakukan deferensiasi sendiri-sendiri, dan pada akhirnya akan dihasilkan karakter dan ciri spesifik yang secara morfologis dan genetik berbeda antar populasi (Hartati et al., 2007). Hasil penelitian pada jenis lain juga menunjukkan bahwa jenis-jenis kayu tropis seperti ulin (Eusideroxylon zwageri) (Rimbawanto et al., 2006), merbau (Intsia bijuga) (Rimbawanto \& Widyatmoko, 2006; Yudhohartono, 2008), pulai gading (Alstonia scholaris) (Hartati et al., 2007), cendana (Santalum album Linn.) (Haryjanto, 2009), gaharu (Gyrinops verstegii) (Widyatmoko et al., 2009), araukaria (Araucaria cunninghamii) (Widyatmoko et al., 2010) dan aren (Arenga pinnata) (Haryjanto et al., 2011) memiliki keragaman genetik di dalam populasi yang besar. Hal ini terjadi karena jenisjenis kayu tropis mempunyai sebaran yang luas dengan populasi yang berukuran besar (Hartati et al., 2007).

Hasil uji DMRT pada Tabel 2 menunjukkan bahwa populasi Muara Wahau menghasilkan bibit dengan rata-rata tinggi, diameter batang, jumlah percabangan, jumlah tunas dan panjang tunas yang jauh lebih baik dari populasi Berau. Hal ini terjadi diduga karena kondisi tegakan hutan kedua lokasi dimana materi genetik diambil cukup berbeda. Di Muara Wahau, pengambilan materi genetik dilakukan di areal IUPHHK-HA yang masih aktif beroperasi dimana kondisi hutannya masih normal, sedangkan di Berau pengambilan materi genetik dilakukan di areal PT. Inhutani I yang sudah tidak beroperasi karena potensi tegakannya sudah tidak memenuhi syarat untuk diusahakan. Pada kondisi hutan yang normal kerapatan pohon per hektar masih tinggi sehingga pada musim berbunga memungkinkan penyerbukan silang (out-crossing) terjadi dengan baik sedang pada hutan dengan potensi tegakan rendah jarak antar pohon menjadi lebar sehingga cenderung terjadi penyerbukan sendiri (selfing). Menurut Finkeldey (2005), selfing dapat menyebabkan depresi silang dalam, dimana hampir semua tanaman yang umumnya menyerbuk silang menunjukkan depresi yang kuat pada parameter fitness. Beberapa ciri fenotipe yang dipengaruhi oleh efek negatif silang dalam diantaranya kelurusan batang, kemampuan menghasilkan keturunan, produktivitas, dan survival tanaman pada pertumbuhan awal.

\section{Variasi antar pohon induk}

Hasil analisis varians (Tabel 1) menunjukkan bahwa pertumbuhan tinggi, diameter batang, jumlah percabangan, jumlah tunas dan panjang tunas bibit meranti tembaga asal cabutan bervariasi antar pohon induk. Performen pohon induk dari populasi Muara Wahau dan Berau disajikan pada Lampiran 1. Hasil analisis varians tersebut sejalan dengan hasil penelitian Mashudi et al. (2012) serta Mashudi \& Susanto (2013) terhadap pertumbuhan bibit meranti tembaga hasil persemaian dari biji. Apabila dikaitkan dengan hasil penelitian tentang keragaman genetik, hal tersebut dapat dipahami karena Rimbawanto dan Suharyanto (2005) serta Cao et al. (2006) menyampaikan bahwa keragaman genetik dalam populasi meranti tembaga cukup tinggi, yaitu masing-masing sebesar $96 \%$ dan $70,2 \%$. Keragaman genetik dalam populasi yang tinggi tersebut menunjukkan bahwa variasi genetik dari individu-individu penyusun populasi cukup tinggi sehingga variasi pertumbuhan anakan antar pohon induk signifikan perbedaannya.

Adanya variasi antar individu (pohon induk) yang tinggi tersebut memberi peluang untuk dilakukannya seleksi, yaitu dengan tujuan untuk memilih individu-individu terbaik sebagai materi untuk membangun tanaman pangkas. Dengan individu-individu terbaik maka bibit yang dihasilkan dari tanaman pangkas adalah bibit-bibit berkualitas. Bibit berkualitas dari materi vegetatif (klon) sangat mendukung program pembangunan hutan tanaman dengan produktivitas tinggi, sebab dari materi klonal seluruh potensi genetik pohon induk akan diwariskan kepada keturunannya. Wick (1985) dalam Adinugraha (2009) menyampaikan bahwa perolehan genetik dengan materi klonal dari individu-individu terseleksi dari suatu populasi akan lebih baik dibanding perolehan genetik dengan materi generatif terseleksi dari populasi tersebut. Hal tersebut dapat diilustrasikan pada Gambar 1. 


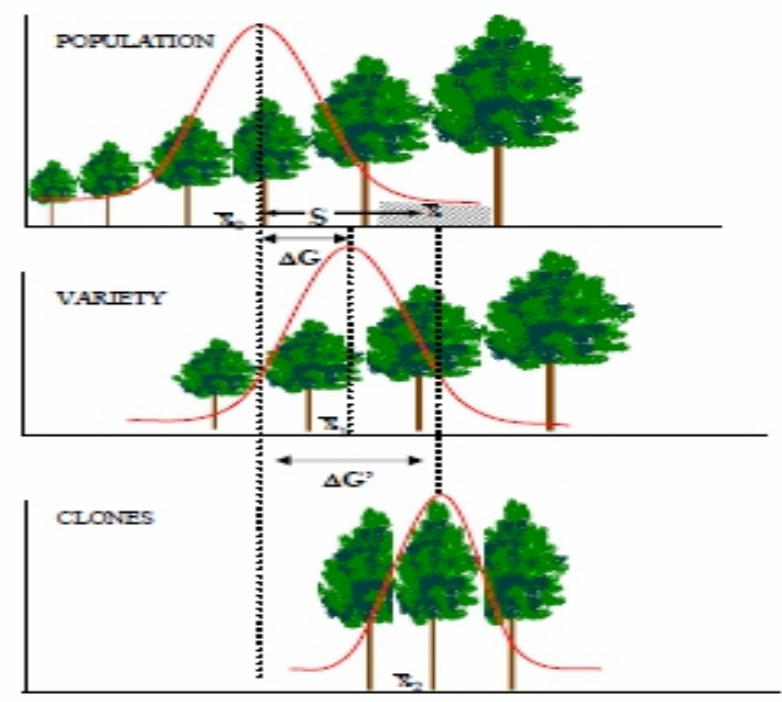

Gambar(Figure) 1. Efek genetik dari metode perbanyakan yang berbeda (Genetic effect of different propagation method): (a) populasi (population); (b) perbanyakan dengan materi generatif (propagation with generatif material) dan (c) perbanyakan dengan klon (propagation with clonal material)(Wick, 1985 dalam Adinugraha, 2009)

Tabel 3. menunjukkan bahwa rata-rata pertumbuhan tinggi bibit meranti tembaga berkisar antara 35,8-136,5 cm, diameter batang berkisar antara 3,53-10,22 $\mathrm{mm}$, jumlah percabangan berkisar antara $1,8-8,8$ buah, jumlah tunas berkisar antara 2,5-9,5 buah dan panjang tunas berkisar antara 9,2-31,2 $\mathrm{cm}$. Pertumbuhan tinggi dan diameter batang tersebut lebih rendah bila dibandingkan dengan pertumbuhan bibit meranti tembaga asal benih pada umur yang sama, yaitu berturut-turut berkisar antara 39,0-173,3 cm dan 5,03-13,63 mm (Mashudi et al., 2012). Hal ini dapat dipahami karena bibit asal cabutan dalam periode waktu yang cukup lama telah mengalami stagnasi pertumbuhan di habitat asalnya, sehingga saat dipindah ke persemaian pertumbuhannya tidak secepat bibit asal benih. Pertumbuhan jumlah tunas dan panjang tunas bibit asal cabutan tidak jauh berbeda dengan daya pertunasan bibit meranti tembaga asal dari benih (Mashudi \& Susanto, 2013). Hal ini terjadi karena cabutan yang diambil dalam penelitian ini relatif masih muda sehingga daya pertunasannya masih tinggi. Menurut Vesk (2006), semakin besar (tua) individu tanaman maka akan semakin menurun daya pertunasannya.
Pertumbuhan tinggi, diameter batang, jumlah percabangan, jumlah tunas dan panjang tunas dengan nilai rata-rata sama dan menempati posisi terbaik didominasi oleh pohon induk dari populasi Muara Wahau (Tabel 3). Hal ini terjadi kemungkinan karena kondisi tegakan hutan di Muara Wahau lebih bagus dibanding kondisi tegakan hutan di Berau, sehingga fenotipe pohon-pohon induk terpilih di Muara Wahau lebih baik dari pohon-pohon induk terpilih di Berau. Kemudian kondisi hutan di Berau dengan jarak antar pohon yang lebar menyebabkan laju penyerbukan silang (outcrossing rate) diduga rendah, sehingga anakan yang dihasilkan cenderung dari hasil selfing. Finkeldey (2005) menyampaikan bahwa individu tanaman hasil selfing dari tanaman yang melakukan penyerbukan silang cenderung berefek negatif terhadap produktivitas.

Dalam kaitannya dengan pembangunan tanaman pangkas, jumlah percabangan yang banyak pada tanaman meranti tembaga sangat diperlukan. Menurut Leppe dan Smits (1988) dalam Wahyuni (2012), cabang (tunas plagiotroph) dapat mengalami pertumbuhan tunas vertikal (orthotrop)(reiterasi proleptis) sebagai materi untuk stek pucuk. Data pada 
Tabel 3 menunjukkan bahwa jumlah percabangan dengan nilai rata-rata sama dan berada pada posisi terbaik ditempati oleh 20 pohon induk (18 pohon induk berasal dari Muara Wahau dan 2 pohon induk berasal dari Berau).

Untuk pengembangan tanaman pangkas, setelah diketahui daya pertunasan (sprouting ability) dari bibit-bibit terseleksi, maka selanjutnya dilakukan uji daya perakaran (rooting ability) melalui perbanyakan vegetatif. Tabel 3 menunjukkan bahwa rerata jumlah tunas dengan nilai sama dan menempati posisi terbaik hanya ditempati oleh 7 pohon induk, sedangkan untuk rerata panjang tunas hanya ditempati oleh 3 pohon induk. Mengingat terbatasnya jumlah pohon induk yang terbaik, maka untuk keperluan uji daya perakaran, jumlah pohon induk yang dilibatkan dapat ditambah dari pohon induk yang berada pada ranking di bawahnya.

Bibit-bibit dari klon dengan daya pertunasan dan daya perakaran tinggi sebelum digunakan untuk pertanaman operasional perlu dilakukan uji lapang terlebih dahulu. Hardiyanto (2004) menyampaikan bahwa uji lapang seyogyanya dilakukan pada beberapa tapak dengan karakteristik yang berbeda, misalnya jenis tanah, tingkat kesuburan, dan sebagainya. Lebih lanjut disampaikan bahwa klon umumnya lebih sensitif terhadap kondisi tapak daripada semai dari benih. Diduga akan terjadi interaksi antar klon dan tapak sangat besar, dalam hal ini klon terbaik pada suatu tapak belum tentu tumbuh baik pula di tapak yang lain. Oleh karena itu semua klon harus diuji di lapangan sebelum dipergunakan untuk pertanaman skala operasional.

\section{KESIMPULAN DAN SARAN}

\section{A. Kesimpulan}

1. Populasi Muara Wahau menghasilkan pertumbuhan tinggi, diameter batang, jumlah percabangan, jumlah tunas dan panjang tunas lebih baik dari populasi Berau, berturut-turut sebesar 108,21 cm, 8,52 mm, 7,73 buah, 6,30 buah dan $20,13 \mathrm{~cm}$.
2. Bibit-bibit terbaik dalam pertumbuhan tinggi, diameter batang, jumlah percabangan, jumlah tunas dan panjang tunas didominasi oleh pohon induk dari populasi Muara Wahau.

3. Pengambilan materi genetik dari tegakan hutan yang normal akan menghasilkan pertumbuhan dan daya pertunasan bibit lebih baik dibanding dengan kondisi tegakan hutan bekas tebangan yang tidak ada pengelolanya.

\section{B. Saran}

Pengambilan materi genetik untuk pembuatan tanaman pangkas sebagai materi untuk perbanyakan vegetatif perlu memperhatikan kondisi populasi dimana materi genetik diambil. Kondisi populasi yang telah mengalami degradasi cukup berat lebih baik tidak digunakan sebagai sumber pengambilan materi genetik.

\section{UCAPAN TERIMA KASIH}

Ucapan terima kasih disampaikan kepada PT. Narkata Rimba yang telah memberikan ijin untuk melakukan pengambilan materi genetik di areal kerjanya. Tidak lupa ucapan terima kasih juga disampaikan kepada Maman Sulaeman dan Susilo yang telah membantu dalam pelaksanaan penelitian dan pengumpulan data.

\section{DAFTAR PUSTAKA}

Adinugraha, H.A. (2009). Peran pembibitan tanaman secara vegetatif dalam pembangunan hutan lestari. Wana Benih 10(1): 1 - 8.

Danu, Siregar, I.Z., Wibowo, C. \& Subiakto, A. (2010). Pengaruh umur sumber bahan stek terhadap keberhasilan stek pucuk meranti tembaga (Shorea leprosula Miq.). Jurnal Penelitian Hutan Tanaman, 7(3): 131 - 139.

Cao, C.P., Finkeldey, R., Siregar, I.Z., Siregar, U.J. and Gailing, O. (2006). Genetic Diversity Within and Among Population of Shorea leprosula Miq. And Shorea parvifolia Dyer (Diptero-carpaceae) in Indonesia Detected by AFLPs. Tree Genetis \& Genomes. 2(4): 225 239.

Finkeldey, R. (2005). Pengantar genetika hutan tropis (Terjemahan). ASEAN-EU University Network Programme (AUNP). pp: 244.

Hardiyanto, E.B. (2004). Silvikultur dan Pemuliaan Acacia mangium. Pembangunan Hutan Tanaman Acacia mangium. Pengalaman di PT. Musi Hutan Persada, Sumatera Selatan.:207-281. 
Hartati, D., Rimbawanto, A., Taryono, Sulistyaningsih, E. \& Widyatmoko, A.Y.P.B.C. (2007). Pendugaan keragaman genetik di dalam dan antar provenan pulai (Alstonia scholaris (L.) Br.) menggunakan penanda RAPD. Jurnal Pemuliaan Tanamann Hutan, 1(2): 89 - 98.

Haryjanto, L., Prastyono \& Ismail, B. (2011). Keragaman genetik empat populasi Arenga pinnata Merr. Berdasarkan Penanda Isozim. Jurnal Pemuliaan Tanaman Hutan, 5(1):13 21.

Haryjanto, L. (2009). Keragaman Genetik Cendana (Santalum album Linn.) di Kebun Konservasi Ex Situ Watusipat, Gunung Kidul dengan Penanda Izozim. Jurnal Pemuliaan Tanaman Hutan, 3(3): 127 - 138

IFSP. (2002). Informasi Singkat Benih Shorea leprosula Miq. Bandung: Direktorat Perbenihan Tanaman Hutan kerjasama dengan Indonesia Forest Seed Project (IFSP) T.H.R. Ir. H. Juanda, Dago Pakar.

Mashudi \& Susanto, M. (2013). Kemampuan bertunas stool slants meranti tembaga (Shorea leprosula Miq.) dari Beberapa Populasi di Kalimantan. Jurnal Pemuliaan Tanaman Hutan, 7(2): 119132.

Mashudi, Pudjiono, S., Rayan \& Sulaeman, M. (2012). Pengaruh asal populasi dan pohon induk terhadap pertumbuhan bibit meranti tembaga (Shorea leprosula Miq.) sebagai materi untuk perbanyakan klonal. Jurnal Penelitian Dipterokarpa, 6(2): 97-108.

Naiem, M., Widiyanto, M.Z., Al-Fauzi. (2014). Progeny test of Shorea leprosula as key point to increase productivity of secondary forest in PT. Balikpapan Forest Industries, East Kalimantan, Indonesia. Procedia Environmental Science, 20: 816-822

Rimbawanto, A. \& Suharyanto. (2005). Keragaman genetik populasi Shorea leprosula Miq. Dan implikasinya untuk Program Konservasi
Genetik. Seminar Nasional Peningkatan Produktivitas Hutan. Fakultas Kehutanan Universitas Gadjah Mada, Yogyakarta P. 373 382.

Rimbawanto, A. \& Widyatmoko, A.Y.P.B.C. (2006). Keragaman genetik empat populasi Intsia bijuga berdasarkan penanda RAPD danimplikasinya bagi program konservasi genetik. Jurnal Penelitian Hutan Tanaman. 3(3): 149-154.

Rimbawanto, A., Widyatmoko, A.Y.P.B.C. \& Harkingto. (2006). Keragaman populasi Eusideroxylon zwageri Kalimantan Timur berdasarkan Penanda RAPD. Jurnal Penelitian Hutan Tanaman, 3(3): 201-208.

Soekotjo. (2009). Teknik Silvikultur Intensif (SILIN). Gadjah Mada University Press. pp: 455.

Vesk, P.A. (2006). Plant size and resprouting ability: trading tolerance and avoidance of damage. Journal of Ecology, 94: 1027-1034.

Wahyuni, K.T. (2012). Pengaruh asal populasi dan tinggi pangkasan terhadap kemampuan bertunas meranti tembaga (Shorea leprosula Miq.). Skripsi.(Tidak dipublikasikan). Fakultas Matematika dan Ilmu Pengetahuan Alam Universitas Negeri Yogyakarta.

Widyatmoko, A.Y.P.B.C., Afritanti, R.D., Taryono \& Rimbawanto, A. (2009). Keragaman genetik Lima Populasi Gyrinops verstegii di Lombok menggunakan penanda RAPD. Jurnal Pemuliaan Tanaman Hutan. 3(1): 1 - 10.

Widyatmoko, A.Y.P.B.C., Lejo, E.S.P., Prasetyaningsih, A., \& Rimbawanto, A. (2010). Keragaman Genetik Populasi Araucaria cunninghamii Menggunakan Penanda RAPD. Jurnal Pemuliaan Tanamann Hutan, 4(2): 63-77.

Yudhohartono, T.P. (2008). Variasi Geetik Beberapa Populasi Merbau (Intsia bijuga O. Ktze) Berdasarkan Penanda Isoenzim. Jurnal Pemuliaan Tanaman Hutan, 2(3): 243 - 251. 
Lampiran(Appendix) 1. Tinggi total, tinggi bebas cabang, diameter batang, kelurusan dan kesehatan pohon induk (Total height, height of trunk, stem diameter, straightness and tree health of parent trees)

\begin{tabular}{|c|c|c|c|c|c|}
\hline $\begin{array}{c}\text { Pohon induk } \\
\text { (Parent } \\
\text { trees) }\end{array}$ & $\begin{array}{l}\text { Tinggi total } \\
\text { (Total height) } \\
\text { (m) }\end{array}$ & $\begin{array}{l}\text { Tinggi bebas } \\
\text { Cabang } \\
\text { (Height of } \\
\text { trunk) } \\
\text { (m) }\end{array}$ & $\begin{array}{c}\text { Diameter } \\
\text { Batang (Stem } \\
\text { diameter) } \\
(\mathrm{cm})\end{array}$ & $\begin{array}{c}\text { Kelurusan } \\
\text { (Straightness) }\end{array}$ & $\begin{array}{c}\text { Kesehatan } \\
\text { (Tree health) }\end{array}$ \\
\hline 1 & 32 & 16 & 55 & Lurus & Sehat \\
\hline 2 & 39 & 25 & 60 & Lurus & Sehat \\
\hline 3 & 31 & 20 & 51 & Lurus & Sehat \\
\hline 4 & 38 & 20 & 60 & Sangat lurus & Sehat \\
\hline 5 & 35 & 21 & 62 & Lurus & Sehat \\
\hline 6 & 39 & 24 & 100 & Lurus & Sehat \\
\hline 7 & 39 & 20 & 102 & Lurus & Sehat \\
\hline 8 & 34 & 23 & 52 & Lurus & Sehat \\
\hline 9 & 36 & 25 & 51 & Lurus & Sehat \\
\hline 10 & 32 & 22 & 61 & Sangat lurus & Sehat \\
\hline 11 & 32 & 20 & 64 & Lurus & Sehat \\
\hline 12 & 30 & 21 & 48 & Lurus & Sehat \\
\hline 13 & 28 & 18 & 45 & Lurus & Sehat \\
\hline 14 & 36 & 22 & 42 & Lurus & Sehat \\
\hline 15 & 35 & 24 & 66 & Lurus & Sehat \\
\hline 16 & 39 & 26 & 89 & Lurus & Sehat \\
\hline 17 & 37 & 24 & 98 & Lurus & Sehat \\
\hline 18 & 33 & 23 & 82 & Sangat lurus & Sehat \\
\hline 19 & 33 & 22 & 62 & Lurus & Sehat \\
\hline 20 & 30 & 22 & 90 & Lurus & Sehat \\
\hline 21 & 24 & 16 & 46 & Lurus & Sehat \\
\hline 22 & 26 & 16 & 46 & Lurus & Sehat \\
\hline 23 & 21 & 14 & 39 & Lurus & Sehat \\
\hline 24 & 32 & 20 & 48 & Lurus & Sehat \\
\hline 25 & 25 & 18 & 42 & Lurus & Sehat \\
\hline 26 & 25 & 16 & 38 & Sangat lurus & Sehat \\
\hline 27 & 30 & 20 & 45 & Lurus & Sehat \\
\hline 28 & 24 & 17 & 40 & Lurus & Sehat \\
\hline 29 & 28 & 18 & 41 & Lurus & Sehat \\
\hline 30 & 28 & 18 & 39 & Lurus & Sehat \\
\hline 31 & 22 & 14 & 37 & Lurus & Sehat \\
\hline 32 & 26 & 15 & 38 & Lurus & Sehat \\
\hline 33 & 25 & 15 & 38 & Lurus & Sehat \\
\hline 34 & 28 & 16 & 40 & Lurus & Sehat \\
\hline
\end{tabular}

Keterangan (Remarks) : Pohon Induk 1- 20 : populasi Muara Wahau, Kalimantan Timur. (Parent tress 1-20: Muara Wahau population, East Kalimantan). Pohon Induk 21- 34 : populasi Berau, Kalimantan Timur. (Parent tress 21-34 : Berau population, East Kalimantan). 